\title{
THE DEVELOPMENT OF THE BACTERIAL FLORA IN NORMAL NEONATES
}

\author{
V. O. Rotimi AND B. I. DUERDEN \\ Department of Medical Microbiology, University of Sheffield Medical School, \\ Beech Hill Road, Sheffield S10 2RX
}

Summary. The development of the bacterial flora of neonates during the first week of life was studied in 23 babies. Specimens of meconium or faeces were collected and swabs taken from the umbilicus and mouth on days $1,2,3$ and 6 . The bacteria present were isolated on a variety of plain and selective media. The predominant faecal organisms by the end of the first week were anaerobes. Bifidobacteria were isolated from all the neonates and bacteroides and clostridia were isolated from $78.3 \%$. Bifidobacteria and bacteroides were present in large numbers; other species were isolated in smaller numbers. Enterococci were isolated from all neonates, enterobacteria from $82.6 \%$, anaerobic cocci from $52 \cdot 2 \%$, and streptococci and staphylococci from $34.8 \%$ each.

Staphylococcus aureus was the predominant species isolated from the umbilicus; it was isolated from $21.7 \%$ of neonates on the first day rising to $87.0 \%$ by the sixth day and represented $49 \%$ of isolates from this site. S. albus, streptococci, enterococci and Escherichia coli were each isolated from a few neonates.

Viridans streptococci ( $31.4 \%$ of isolates) and Streptococcus salivarius $(25 \cdot 1 \%)$ were the commonest species recovered from the mouth. They were present from $8 \mathrm{~h}$ after birth; $S$. albus and Neisseria spp. were isolated later on the first day, and anaerobic species of Veillonella and Bifidobacterium appeared on the second day.

\section{INTRODUCTION}

The normal fetus is sterile until shortly before birth, as long as the amniotic membrane remains intact. After birth, the neonate rapidly acquires commensal bacteria that colonise the skin and mucous membranes. The host defence mechanisms are not well developed at this stage and some commensals may become opportunist pathogens, particularly in compromised neonates who must remain in hospital for the treatment of congenital abnormalities.

The gastrointestinal tract is colonised soon after birth, mainly by facultative bacteria. Mata, Mejicanos and Jimenez (1972), Bullen, Tearle and Willis (1976) and Long and Swenson (1977) have shown that anaerobes colonise the neonatal gastrointestinal tract during the first week of life and are greater in number and variety than aerobes or facultative species. Subsequently, only 
micro-organisms that can adapt to live in this mixed population of facultative and anaerobic species will colonise the various parts of the tract and become part of the resident flora.

Nolte (1977) suggested that the body acquires its first microflora of the skin, nose, mouth and conjuctiva from the mother's birth canal during normal vaginal delivery. The local environment is also important as a source from which neonates acquire bacteria (Mortimer et al., 1966; Nolte, 1977; Harvey, 1979; Shinebaum, Cooke and Brayson, 1979). The colonisation of the skin surface starts at the umbilical stump (Mortimer et al., 1966). The role of the umbilicus as the initial colonisation site and subsequent endogenous source of serious systemic infection in individual infants (Fairchild et al., 1958; Williams and Oliver, 1969; Hargiss and Larson, 1978) and in the spread of pyoderma and generalised infection amongst infants in the same nursery (Isbister, 1951; Jellard, 1957; Harvey, 1979) has been stressed.

The normal commensal flora of the oral cavity is more complex. The mouth is sterile at birth but is rapidly colonised by bacteria derived from attendants and the local environment. By the second day of life, aerobes and facultative species can be detected, but strict anaerobes do not appear until after the eruption of the deciduous teeth (Hurst, 1957; McCarthy, Snyder and Parker, 1965).

The aim of the present investigations was to study the early acquisition of commensal bacteria in detail.

\section{MATERIALS AND METHODS}

Subjects. Twenty-three normal healthy neonates were studied during the first week of life; all were born at the Jessop Hospital for Women, Sheffield, and remained in hospital for at least 6 days. The study period was 7 months from January to July 1979. All the babies were breast fed and had supplementary bottle feeds of Cow and Gate Premium Milk.

Specimens. Samples of freshly voided meconium or faeces were collected on albumin-coated cotton-wool swabs (Exogen Ltd, Dumbarton Road, Glasgow) or, when this was not possible, rectal swabs containing approximately $500 \mathrm{mg}$ of faecal material were collected. The normal flora of the umbilical stump and mouth was sampled by albumin-coated cotton-wool swabs. For the oral specimen the sample area comprised the buccal mucosa, the surface of the tongue and the saliva. The sets of swabs were collected on four days (days 1,2,3 and 6) during the first week of life; a total of 92 sets of specimens were collected from the 23 neonates.

The swabs were broken immediately into $6 \mathrm{ml}$ of Amies's transport medium (Amies and Douglas, 1967) in a screw-capped vial and the cap was screwed tight. All specimens were processed within $1 \mathrm{~h}$ from the time of collection. The transport procedure was evaluated under simulated test conditions with one strain each of Bacteroides fragilis, B. vulgatus and $B$. asaccharolyticus. Sterile swabs were dipped in 48-h broth cultures diluted to contain $10^{3}$ colony-forming units/ml and placed in Amies's transport medium; after holding for 12, 24, 48 and $96 \mathrm{~h}$ on the bench the swabs were plated on BM-kanamycin agar and incubated anaerobically at $37^{\circ} \mathrm{C}$ for $48 \mathrm{~h}$. A heavy growth of each test strain was recovered from the swabs. $B$. vulgatus, $B$. thetaiotaomicron, $B$. ruminicola and Clostridium perfringens were also isolated from specimens of faeces held on swabs in Amies's transport medium at room temperature for $96 \mathrm{~h}$.

Culture media. The solid media used for isolation of the various organisms from each specimen were: blood agar [Oxoid Columbia Agar Base, CM331, with Defibrinated Horse Blood (Wellcome) 7.5\%]; chocolate agar [Oxoid Nutrient Agar Base with $10 \%$ Horse Blood (Wellcome) heated in a water bath at $80^{\circ} \mathrm{C}$ for 4-5 min]; Sabouraud's Agar (Oxoid, CM41a); 
MacConkey Agar (Oxoid, CM7b); Rogosa Agar (Oxoid, $p$ H 5.8); neomycin blood agar [Oxoid Blood Agar Base No. 2 with 7.5\% Defibrinated Horse Blood (Wellcome) and neomycin 75 $\mu \mathrm{g} / \mathrm{ml}$; ; BM-kanamycin agar (Holbrook, Ogston and Ross, 1978); sucrose agar (Drasar, 1967); Reinforced Clostridial Medium (Oxoid) with $0.75 \%$ New Zealand agar and $0.1 \%$ cotton blue at pH 5.0 (Willis et al., 1973).

The neomycin blood agar was used only for the faecal specimens and the sucrose agar only for the oral specimens.

Inoculation of media. The cotton-wool swabs were removed from the transport medium and rolled on the surface of a sector of each plate to make an inoculum well; the inoculum was streaked over the remainder of the plate by a standard plating method (Gillies and Dodds, 1976) with a sterile 2-mm wire loop. This enabled the numbers of the individual bacterial species isolated to be scored semiquantitatively by a method analogous to that of McGeachie and Kennedy (1963).

Incubation. One blood-agar plate, the MacConkey agar, the sucrose agar and the Sabouraud's agar were incubated aerobically at $37^{\circ} \mathrm{C}$ and inspected after 24 and $48 \mathrm{~h}$. The chocolateagar plate was incubated in air plus $10 \% \mathrm{CO}_{2}$ for $24 \mathrm{~h}$. The remaining plates were incubated anaerobically for a minimum of $48 \mathrm{~h}$. The anaerobic procedure of Collee et al. (1972) was followed in all essential aspects; incubation was at $37^{\circ} \mathrm{C}$ in an atmosphere of $\mathrm{H}_{2} 90 \%$ and $\mathrm{CO}_{2}$ $10 \%$. A slope of Simmons's citrate medium seeded with Pseudomonas aeruginosa was included in each jar as a control.

Identification of isolates. Representative colonies of each colony type were subcultured for identification. The aerobes and facultative species were identified by the methods of Cowan (1974). Particular consideration was given to the identification of anaerobic bacteria. They were identified by the methods of Duerden et al. (1976, 1980); Hafiz and Oakley (1976), and Willis (1977) and methods developed in this laboratory (Rotimi, Faulkner and Duerden, 1980). On the basis of the results obtained by the above methods, isolates were placed in broad groups similar to those of Drasar (1967).

\section{RESULTS \\ Umbilical flora}

Staph. aureus was the most common isolate from the umbilical swabs. It represented $50 \%$ of isolates on the first day and remained the predominant cultivable species; $43.5 \%$ of strains isolated on the sixth day were Staph. aureus. Staph. albus was the next most common isolate; $40 \%$ of all isolates on the first day were Staph. albus but this fell to $13 \%$ on the sixth day. Apart from non-haemolytic streptococci, which represented $10 \%$ of isolates, no other bacteria were recovered from the umbilical swabs on the first day. Other species appeared on the second day but remained at consistently low numbers (table I). Semi-quantitative scoring of the density of growth on the primary plates showed that Staph. aureus occurred in the largest numbers with a mean score of $4^{+}$. The other species grew with an average density score of $2^{+}-3^{+}$. The cumulative percentages and the semi-quantitative scores of the species isolated are shown in table I. The numbers of babies colonised by the different species on each test day are shown in table II.

\section{Oral flora}

The $\alpha$-haemolytic streptococci (viridans streptococci) were the commonest species isolated from the mouth swabs (table III). They represented $30.9 \%$ of a 
TABLE I

Species isolated from the umbilicus of 23 healthy normal neonates during the first week of life

\begin{tabular}{|c|c|c|c|c|c|c|}
\hline \multirow{2}{*}{$\begin{array}{l}\text { Species } \\
\text { or } \\
\text { group }\end{array}$} & \multicolumn{4}{|c|}{$\begin{array}{l}\text { Percentage of total isolates } \\
\text { on each day represented by } \\
\text { the given bacteria on }\end{array}$} & \multirow{2}{*}{$\begin{array}{l}\text { Cumulative } \\
\text { percentage of } \\
\text { total isolates }\end{array}$} & \multirow{2}{*}{$\begin{array}{l}\text { Mean semi- } \\
\text { quantitative } \\
\text { score for each } \\
\text { species* }\end{array}$} \\
\hline & day 1 & day 2 & day 3 & day 6 & & \\
\hline Staph. aureus & 50 & $53 \cdot 1$ & $48 \cdot 8$ & $43 \cdot 5$ & 48.9 & $4^{+}$ \\
\hline Staph. albus & 40 & $15 \cdot 6$ & $12 \cdot 2$ & $13 \cdot 0$ & $20 \cdot 2$ & $3^{+}$ \\
\hline Viridans streptococci & 0 & $6 \cdot 3$ & $4 . \overline{9}$ & 6.5 & $4 \cdot \overline{4}$ & $2^{+}$ \\
\hline $\begin{array}{l}\text { Non-haemolytic } \\
\text { streptococci }\end{array}$ & 10 & $9 \cdot 4$ & $14 \cdot 6$ & $13 \cdot 0$ & $11 \cdot 8$ & $2^{+}$ \\
\hline E. coli & 0 & $6 \cdot 3$ & $7 \cdot 3$ & 8.7 & $5 \cdot 6$ & $2^{+}$ \\
\hline Str. faecalis & 0 & $9 \cdot 4$ & $12 \cdot 2$ & $15 \cdot 2$ & $9 \cdot 2$ & $2^{+}$ \\
\hline
\end{tabular}

* See Methods.

total of 233 oral isolates. The next commonest was Str. salivarius with 59 $(25.3 \%)$ isolates. Staph. albus and anaerobic cocci made up $14 \cdot 2 \%$ and $12.4 \%$ of isolates respectively. Other anaerobes, Haemophilus influenzae, Neisseria spp., enterobacteria and enterococci were found in a few subjects only. No $\beta$-haemolytic streptococci or Candida spp. were isolated. Semi-quantitative scoring of the density of growth on the primary plates showed that viridans streptococci and Str. salivarius were the most numerous species with mean scores of $4^{+}$. Anaerobic cocci gave a score of $3^{+}$; enterococci, H. influenzae and staphylococci gave a score of $2^{+}$; and enterobacteria occurred in only small numbers $\left(1^{+}\right.$score $)$.

The numbers of babies colonised by the different species are shown in table III. About $65 \%$ of the neonates were colonised by viridans streptococci on the first day and nearly all were colonised by these organisms by the sixth day. The only baby not colonised had been given oral and parenteral antibiotics because of overwhelming staphylococcal infection. Str. salivarius was also common

TABLE II

Colonisation of the umbilical stump in 23 neonates

\begin{tabular}{l|cccc}
\hline $\begin{array}{c}\text { Species } \\
\text { or } \\
\text { group }\end{array}$ & \multicolumn{4}{c}{$\begin{array}{c}\text { Number of neonates colonised } \\
\text { by the given bacteria on }\end{array}$} \\
\cline { 2 - 5 } day 1 & day 2 & day 3 & day 6 \\
\hline $\begin{array}{l}\text { Staph. aureus } \\
\text { Staph. albus }\end{array}$ & 5 & 17 & 20 & 20 \\
$\begin{array}{l}\text { Streptococci: } \\
\alpha \text {-haemolytic }\end{array}$ & 4 & 5 & 5 & 7 \\
$\beta$-haemolytic & 0 & 2 & 3 & 3 \\
non-haemolytic & 0 & 0 & 0 & 0 \\
$E$. coli & 1 & 3 & 6 & 6 \\
Enterococci & 0 & 2 & 3 & 4 \\
\hline
\end{tabular}


TABLE III

Bacterial colonisation of the mouth in 23 neonates

\begin{tabular}{|c|c|c|c|c|c|c|}
\hline \multirow{2}{*}{$\begin{array}{l}\text { Species } \\
\text { or group }\end{array}$} & \multicolumn{4}{|c|}{$\begin{array}{l}\text { Number of neonates colonised } \\
\text { by the given bacteria on }\end{array}$} & \multirow{2}{*}{$\begin{array}{l}\text { Cumulative percentage } \\
\text { of total isolates }\end{array}$} & \multirow{2}{*}{$\begin{array}{l}\text { Mean semi- } \\
\text { quantitative } \\
\text { score }\end{array}$} \\
\hline & day 1 & day 2 & day 3 & day 6 & & \\
\hline $\begin{array}{l}\text { Viridans streptococci } \\
\text { Str. salivarius } \\
\text { Staph. albus } \\
\text { Anaerobic cocci } \\
\text { H. influenzae } \\
\text { Bifidobacteria } \\
\text { Neisseria spp. } \\
\text { Enterobacteria } \\
\text { Enterococci }\end{array}$ & $\begin{array}{l}15 \\
8 \\
6 \\
0 \\
0 \\
0 \\
1 \\
0 \\
0\end{array}$ & $\begin{array}{r}17 \\
14 \\
7 \\
7 \\
3 \\
2 \\
2 \\
1 \\
1\end{array}$ & $\begin{array}{r}20 \\
18 \\
12 \\
10 \\
3 \\
3 \\
3 \\
3 \\
2\end{array}$ & $\begin{array}{r}22 \\
19 \\
8 \\
12 \\
3 \\
5 \\
3 \\
2 \\
2\end{array}$ & $\begin{array}{r}30 \cdot 9 \\
25 \cdot 3 \\
14 \cdot 2 \\
12 \cdot 4 \\
4 \cdot 3 \\
4 \cdot 3 \\
3 \cdot 8 \\
2 \cdot 6 \\
2 \cdot 2\end{array}$ & $\begin{array}{l}4^{+} \\
4^{+} \\
2^{+} \\
3^{+} \\
2^{+} \\
2^{+} \\
2^{+} \\
1^{+} \\
2^{+}\end{array}$ \\
\hline
\end{tabular}

and was isolated from most babies by the sixth day. Staph. albus was isolated from $35 \%$ of the babies on the first day, $80 \%$ on the third day, and $61 \%$ on the sixth day. Neisseria spp., $H$. influenzae, enterococci and enterobacteria were minor or transient members of the oral flora during the study period. Anaerobes were not isolated on the first day, but by the second day seven babies were colonised by anaerobic cocci and two by bifidobacteria.

\section{Faecal flora}

The cumulative analysis of the isolates from 92 specimens from 23 neonates during the first 6 days of life showed that the alimentary tract of all the babies was colonised by enterococci and gram-positive, non-sporing anaerobic rods and that $c .75 \%$ were colonised by clostridia, gram-negative anaerobic rods, and enterobacteria. Anaerobic cocci (gram-negative and gram-positive) were isolated from $>50 \%$ of the babies. Staphylococci and streptococci were isolated from $<50 \%$ of the babies. Examination of the sequential development of the neonatal faecal flora (table IV) showed that only staphylococci, streptococci and enterococci appeared on the first day of life and representatives of all the bacterial groups had been isolated by the second day, when enterococci, staphylococci and gram-positive non-sporing anaerobic rods were isolated from $>66 \%$ of the infants. On the third day, enterococci were isolated from all the neonates and gram-positive, non-sporing anaerobic rods from $96 \%$; there was a significant increase in the isolation of clostridia, gram-negative anaerobic rods and enterobacteria. The isolation rate of staphylococci remained at $c .74 \%$ on the third day but fell to $48 \%$ by the sixth day, demonstrating the transient colonisation of the gastrointestinal tract by this genus.

Aerobic and facultative species. Str. faecalis was the commonest facultative species isolated from the specimens of faeces; it was isolated from one baby on the first day, 20 on the second day and from all of them by the sixth day. It also 
TABLE IV

Development of neonatal faecal flora during the first 6 days of life in 23 neonates

\begin{tabular}{|c|c|c|c|c|}
\hline \multirow{2}{*}{$\begin{array}{l}\text { Bacterial } \\
\text { group }\end{array}$} & \multicolumn{4}{|c|}{$\begin{array}{c}\text { Number of neonates colonised } \\
\text { by the given bacteria on }\end{array}$} \\
\hline & day 1 & day 2 & day 3 & day 6 \\
\hline Enterobacteria & 0 & 12 & 16 & 19 \\
\hline Enterococci & 1 & 21 & 23 & 23 \\
\hline Pseudomonads & 0 & 0 & 0 & 1 \\
\hline Streptococci & 2 & 4 & 4 & 8 \\
\hline Staphylococci & 6 & 17 & 17 & 11 \\
\hline \multicolumn{5}{|l|}{ Non-sporing anaerobes } \\
\hline Gram-negative rods & 0 & 7 & 14 & 18 \\
\hline Gram-positive rods & 0 & 17 & 22 & 23 \\
\hline Clostridia & 0 & 6 & 16 & 18 \\
\hline Anaerobic cocci & 0 & 3 & 8 & 12 \\
\hline
\end{tabular}

accounted for $31 \%$ of the facultative strains isolated from the faecal specimens (table V). The next commonest species, E. coli, appeared on the second day and was isolated from 16 babies by the end of the first week. It also represented $18 \%$ of the total facultative strains isolated from the faecal specimens. Staph. albus, which accounted for $20 \%$ of the total isolates, was isolated from 15 and 16 babies on the second and third days but from only eight babies on the sixth day. At the end of the study period, Str. faecium and non-haemolytic streptococci had been isolated from $c .30 \%$ of the babies. Other facultative species, Klebsiella aerogenes, Proteus mirabilis, Staph. aureus and Serratia spp., were isolated from only a small proportion of the babies. Pseudomonas aeruginosa was first isolated on the sixth day and from only one subject. No $\beta$-haemolytic streptococci or Candida spp. were isolated.

Anaerobic species (table VI). No intestinal anaerobes were isolated from

TABLE V

The relative proportions of aerobic and facultative species in the neonatal faecal flora

\begin{tabular}{|c|c|c|c|c|c|}
\hline \multirow{2}{*}{$\begin{array}{c}\text { Species } \\
\text { or } \\
\text { group }\end{array}$} & \multicolumn{4}{|c|}{$\begin{array}{l}\text { Percentage of facultative } \\
\text { isolates represented by } \\
\text { the given bacteria on }\end{array}$} & \multirow{2}{*}{$\begin{array}{l}\text { Cumulative } \\
\text { percentage }\end{array}$} \\
\hline & day 1 & day 2 & day 3 & day 6 & \\
\hline E. coli & 0 & $19 \cdot 6$ & 16.9 & $20 \cdot 7$ & $18 \cdot 3$ \\
\hline$K$. aerogenes & 0 & 1.8 & 5.6 & 7.8 & $5 \cdot 2$ \\
\hline Pr. mirabilis & 0 & 0 & 1.4 & 3.9 & 1.9 \\
\hline Serratia spp. & 0 & 0 & $1 \cdot 4$ & $1 \cdot 3$ & 0.9 \\
\hline Str. faecalis & $11 \cdot 1$ & $35 \cdot 7$ & $31 \cdot 0$ & 29.9 & $31 \cdot 0$ \\
\hline Str. faecium & 0 & 5.4 & $11 \cdot 3$ & $10 \cdot 4$ & 8.9 \\
\hline $\begin{array}{l}\text { Non-haemolytic } \\
\text { streptococci }\end{array}$ & $22 \cdot 2$ & $7 \cdot 1$ & 5.6 & $10 \cdot 4$ & $8 \cdot 4$ \\
\hline Staph. aureus & 0 & $\begin{array}{r}3.6 \\
26\end{array}$ & $7 \cdot 0$ & 3.9 & $4 \cdot 7$ \\
\hline $\begin{array}{l}\text { Staph. albus } \\
P . \text { aeruginosa }\end{array}$ & $\begin{array}{c}66 \cdot 7 \\
0\end{array}$ & $\begin{array}{c}26 \cdot 8 \\
0\end{array}$ & $\begin{array}{c}19 \cdot 7 \\
0\end{array}$ & $\begin{array}{r}10.4 \\
1.3\end{array}$ & $\begin{array}{r}20 \cdot 2 \\
0.5\end{array}$ \\
\hline
\end{tabular}


TABLE VI

Colonisation of healthy normal neonates by anaerobic bacteria

\begin{tabular}{|c|c|c|c|c|}
\hline \multirow{2}{*}{$\begin{array}{l}\text { Bacterial } \\
\text { group }\end{array}$} & \multicolumn{4}{|c|}{$\begin{array}{c}\text { Percentage of neonates colonised } \\
\text { by the given group on }\end{array}$} \\
\hline & day 1 & day 2 & day 3 & day 6 \\
\hline Bacteroides & 0 & $30 \cdot 4$ & $60 \cdot 9$ & $78 \cdot 3$ \\
\hline Fusobacteria & 0 & 0 & 0 & 0 \\
\hline Eubacteria & 0 & 13 & 34.8 & 34.8 \\
\hline Bifidobacteria & 0 & 73.9 & $91 \cdot 3$ & 100 \\
\hline Lactobacilli & 0 & $21 \cdot 7$ & 26.7 & $39 \cdot 1$ \\
\hline Veillonellae & 0 & $4 \cdot 3$ & 8.7 & $52 \cdot 2$ \\
\hline Anaerobic gram + ve cocci & 0 & 8.7 & $26 \cdot 1$ & 34.8 \\
\hline Clostridia & 0 & $26 \cdot 1$ & 69.6 & $78 \cdot 3$ \\
\hline
\end{tabular}

any of the babies on the first day of life, but on the second day, bifidobacteria were present in the faecal specimens from 17 babies $(73.9 \%)$; Bacteroides of the fragilis group were isolated from seven babies, clostridia from six, lactobacilli from five, eubacteria from three, gram-positive anaerobic cocci from two and veillonellae from only one baby. The isolation of bifidobacteria remained consistently high to the end of the first week of life. By the third day the isolation rate of bacteroides was approaching the adult level and at the end of the first week, 18 babies were colonised. The isolation of clostridia also increased from the third day onwards and 18 babies were colonised by the sixth day. Veillonellae were isolated from 12 babies by day six. The other anaerobes-lactobacilli, eubacteria and gram-positive cocci-were isolated from $>33 \%$ of the babies.

All of the Bacteroides strains isolated belonged to the fragilis group (table VII). B. fragilis was isolated from two babies on the second day, and six and seven babies on the third and sixth days, but $B$. vulgatus was isolated from a consistently higher number of babies on each of the three days with 13 babies colonised by the sixth day. The isolation of $B$. thetaiotaomicron was similar to

TABLE VII

Bacteroides and Clostridium spp. in faeces of 23 neonates

\begin{tabular}{|c|c|c|c|c|}
\hline \multirow[b]{2}{*}{ Species } & \multicolumn{4}{|c|}{$\begin{array}{l}\text { Percentage of neonates colonised } \\
\text { by the given species on }\end{array}$} \\
\hline & day 1 & day 2 & day 3 & day 6 \\
\hline $\begin{array}{l}\text { B. vulgatus } \\
\text { B. thetaiotaomicron } \\
\text { B. fragilis } \\
\text { B. distasonis } \\
\text { C. perfringens } \\
\text { C. difficile } \\
\text { C. paraputrificum } \\
\text { C. tertium } \\
\text { C. cochlearum }\end{array}$ & $\begin{array}{l}0 \\
0 \\
0 \\
0 \\
0 \\
0 \\
0 \\
0 \\
0\end{array}$ & $\begin{array}{c}21 \cdot 7 \\
8 \cdot 7 \\
8 \cdot 7 \\
4 \cdot 3 \\
21 \cdot 7 \\
0 \\
13 \cdot 0 \\
4 \cdot 3 \\
0\end{array}$ & $\begin{array}{r}39 \cdot 1 \\
21 \cdot 7 \\
26 \cdot 1 \\
4 \cdot 3 \\
52 \cdot 2 \\
13 \cdot 0 \\
13 \cdot 0 \\
8 \cdot 7 \\
4 \cdot 3\end{array}$ & \begin{tabular}{r|}
$56 \cdot 5$ \\
$43 \cdot 5$ \\
$30 \cdot 4$ \\
$8 \cdot 7$ \\
$69 \cdot 6$ \\
$17 \cdot 4$ \\
$13 \cdot 0$ \\
$8 \cdot 7$ \\
$8 \cdot 7$
\end{tabular} \\
\hline
\end{tabular}


that of $B$. fragilis on days 2 and 3, but was significantly greater on the sixth day with 10 babies colonised. B. distasonis was isolated from only two babies by the sixth day. The commonest Clostridium sp. isolated from these babies was $C$. perfringens; it was isolated from five babies on the second day and from 16 on day 6. C. difficile was isolated from four babies during this study period. Other clostridia were isolated from only a few babies.

The semi-quantitative assessment of the density of growth of all the genera isolated is shown in table VIII. The predominant organisms were Bifidobacterium spp. with a mean score of $5^{+}$, closely followed by Bacteroides spp. with a mean score of $4^{+}$. Eubacteria, lactobacilli, anaerobic cocci and enterobacteria each had a mean score of $3^{+}$. Enterococci and non-haemolytic streptococci were present in smaller numbers (mean score $2^{+}$) and the score for clostridia was only $1-2^{+}$. Staph. albus had the lowest mean score $\left(1^{+}\right)$that we recorded.

TABLE VIII

Semi-quantitative assessment of bacterial species in the neonatal faecal fora

\begin{tabular}{l|cccccc}
\hline \multirow{1}{*}{$\begin{array}{l}\text { Bacterial } \\
\text { group }\end{array}$} & \multicolumn{4}{|c}{$\begin{array}{c}\text { Mean score for the } \\
\text { given group on }\end{array}$} \\
\cline { 2 - 7 } day 1 & day 2 & day 3 & day 6 & $\begin{array}{c}\text { Mean } \\
\text { overall } \\
\text { score }\end{array}$ \\
\hline Enterobacteria & 0 & $2^{+}$ & $3^{+}$ & $3^{+}$ & $3^{+}$ \\
Enterococci & $1^{+}$ & $2^{+}$ & $2^{+}$ & $3^{+}$ & $2^{+}$ \\
$\begin{array}{l}\text { Non-haemolytic } \\
\text { streptococci }\end{array}$ & $1^{+}$ & $1^{+}$ & $2^{+}$ & $3^{+}$ & $2^{+}$ \\
Staphylococci & $1^{+}$ & $1^{+}$ & $2^{+}$ & $2^{+}$ & $1^{+}$ \\
Bacteroides & 0 & $3^{+}$ & $4^{+}$ & $5^{+}$ & $4^{+}$ \\
Bifidobacteria & 0 & $3^{+}$ & $5^{+}$ & $5^{+}$ & $5^{+}$ \\
Clostridia & 0 & $1^{+}$ & $2^{+}$ & $2^{+}$ & $2^{+}$ \\
Eubacteria & 0 & $2^{+}$ & $3^{+}$ & $4^{+}$ & $3^{+}$ \\
Lactobacilli & 0 & $2^{+}$ & $3^{+}$ & $4^{+}$ & $3^{+}$ \\
Anaerobic cocci & 0 & $2^{+}$ & $2^{+}$ & $3^{+}$ & $3^{+}$ \\
\hline
\end{tabular}

\section{Discussion}

In the present study, sterile swabs were the only practical method for sampling the neonatal flora despite the potential disadvantages of toxicity, desiccation, overgrowth by more vigorous organisms, loss of viability in transit and adhesion of organisms to the swab. The commercially available cottonwool swabs used are non-toxic (Collee et al., 1974). Amies's transport medium was used to prevent desiccation and loss of viability in transit, and the delay between obtaining the samples and processing in the laboratory was reduced to a minimum. To overcome the problem of adhesion of organisms to the swab, the faecal swab was heavily loaded with faeces and then agitated in the transport medium by vortex mixing before seeding on plates.

The newborn infant is exposed to bacteria from the mother's vaginal and faecal microflora during birth and then from the external environment. Col- 
onisation occurs then from the external environment. Colonisation occurs rapidly; from $6 \mathrm{~h}$ onwards cultivable bacteria are present in the mouth. The quality and quantity of the cultivable microflora varies and changes from site to site, especially in the oral cavity (Socransky and Manganiello, 1971), but in general the types of bacteria that colonise the various anatomical sites are remarkably consistent.

The high incidence of umbilical colonisation by Staph. aureus found in the present study is similar to that reported by Fairchild et al. (1958), Payne et al. (1965) and Johnson et al. (1976). This may be important in relation to neonatal infection (Holve and Smith, 1955; Jellard, 1957), but the incidence of colonisation does not always correlate with the incidence of infection (Fairchild et al., 1958; Harvey, 1979). Only one baby developed staphylococcal infection and this low incidence of infection may indicate that most of the colonising strains were relatively avirulent. Enterococci and enterobacteria were isolated as umbilical contaminants from most babies; this was expected because the umbilical stump is a moist area (Wilson and Miles, 1975).

Viridans streptococci were the predominant species isolated from the mouths of the neonates; the only baby from whom they were never isolated was treated with an antibiotic because of overwhelming staphylococcal infection. The related but non-haemolytic Str. salivarius was also common but was isolated less frequently than the viridans streptococci. These results are in agreement with the findings that the neonatal oral microflora consists mainly of aerobic and facultative bacteria and in particular that the cheek mucosa and the tongue epithelium encourage the establishment of the viridans streptococci and Str. salivarius which are regular oral commensals from the second day of life (McCarthy et al., 1965; Zinner and Jablon, 1969; Carlsson et al., 1970; Socransky, 1970; Socransky and Manganiello, 1971; Hardie and Bowden, 1974; Nolte, 1977). In the present study the viridans streptococci and Str. salivarius were predominant from the first day of life. They proliferate on the mucous membranes and do not depend upon the teeth for survival (Socransky and Manganiello, 1971). The most significant anaerobes isolated from the mouth were veillonellae; the Bacteroides spp. and spirochaetes that inhabit the gingival crevice and dental plaque were not isolated. Lay and Russell (1972) isolated Candida spp. from the mouths of $5.7 \%$ of 140 infants at birth and from $10.7 \%$ by the seventh day, but the absence of Candida spp. in the present series supports the finding of McCarthy et al. (1965) that Candida spp. are not invariably found.

In the present study the neonatal faecal flora was predominantly anaerobic. The contributions of bifidobacteria, bacteroides, enterococci and enterobacteria were similar to those found in various studies by Mata et al. (1972), Ellis-Pegler, Crabtree and Lambert (1975), Bullen, Tearle and Willis (1976), Long and Swenson (1977) and Albert et al. (1978). Bifidobacteria are the predominant faecal bacteria in breast-fed infants (Mata and Urrutia, 1971; Bullen et al., 1976) and during the first week of life in infants fed with Premium Milk (Bullen, Tearle and Stewart, 1977). In our studies, bifidobacteria represented c. $25 \%$ of all strains identified. Bacteroides of the fragilis group are 
isolated from $60-100 \%$ of specimens of adult faeces (Drasar, Shiner and McLeod et al., 1969; Brown, 1977) and the present results confirm those of Long and Swenson (1977) that they are established with a similar frequency by the sixth day of life. The high incidence of clostridia in the present study was similar to that found by Ellis-Pegler et al. (1975) and approached the rate of isolation from adults. Other workers have isolated clostridia in much smaller numbers from similar babies (Mata and Urrutia, 1971; Albert et al., 1978). The differences may be due to different laboratory methods or to the type of feeds given to the infants. C. difficile was isolated from only four normal healthy babies although other workers have isolated this species from the meconium in a larger number of neonates (Smith et al., 1980).

Str. faecalis and $E$. coli were the commonest facultative species isolated from the neonatal faeces and were isolated in large numbers. The proportion of $E$. coli is increased in babies fed with cow's milk preparations (Gyllenberg and Roine, 1957; Ellis-Pegler et al., 1975; Bullen et al., 1977) and all the babies in the present study received supplementary feeds of a commercial cow's-milk preparation. Other enterobacteria were isolated in very small numbers and Staph. albus was probably a transient member of the faecal flora.

The present study has shown that normal neonates given feeds supplemented with cow's milk in a maternity hospital rapidly acquire a common faecal bacterial flora that is similar in composition to the normal adult faecal flora.

We thank Professor M.G. McEntegart for his support and enthusiasm, the matron, sisters and staff on Ward 1A Jessop Hospital for Women, Sheffield, for their help in collecting specimens, and Mrs Hazel Bland for typing the manuscript.

V.O.R. is grateful to The Wellcome Trust for financial support.

\section{REFERENCES}

Albert, M. J., Bhat, P., Rajan, D., Maiya, P. P., Pereira, S. M. and Baker, S. J. 1978. Faecal flora of South Indian infants and young children in health and with acute gastroenteritis. J. med. Microbiol., 11, 137.

Amies, C. R. AND Douglas, J. I. 1967. A modified formula for the preparation of Stuart's transport medium. Can. J. publ. Hlth., 58, 296.

BRown, J. P. 1977. Role of gut bacterial flora in nutrition and health. Review of recent advances in bacteriological techniques, metabolism and factors affecting floral composition. C.R.C. critical Rev. Food, Sci. Nutr., 8, 229.

Bullen, C. L., Tearle, P. V. and Stewart, M. G. 1977. The effect of "Humanised" milks and supplemented breast feeding on the faecal flora of infants. J. med. Microbiol., 10, 403.

Bullen, C.L., Tearle, P. V. AND Willis, A. T. 1976. Bifidobacteria in the intestinal tract of infants: an in-vivo study. J. med. Microbiol., 9, 325.

Carlsson, J., Grahnen, H., Jonsson, G. and Wikner, S. 1970. Early establishment of Streptococcus salivarius in the mouth of infants. J. dent. Res., 49, 415.

Collee, J. G., Watt, B., Brown, R. AND Johnstone, S. 1974. The recovery of anaerobic bacteria from swabs. J. Hyg., Camb., 72, 339.

Collee, J. G., Watt, B., Fowler, E. B. AND Brown, R. 1972. An evaluation of the Gas-Pak system in the culture of anaerobic bacteria. J. appl. Bact., 35, 71 . 
Cowan, S. T. 1974. Manual for the identification of medical bacteria, 2nd ed., Cambridge University Press, Cambridge.

Drasar, B. S. 1967. Cultivation of anaerobic intestinal bacteria. J. Path. Bact., 94, 417.

Drasar, B. S., ShINer, M. AND MCLeod, G. 1969. Studies on the intestinal flora. I. Bacterial flora of the gastrointestinal tract in healthy and achlorhydric patients. Gastroenterology, 56, 71 .

Duerden, B. I., Collee, J. G., Brown, R., Deacon, A. G. And Holbrook, W. P. 1980. A scheme for the identification of clinical isolates of gram-negative anaerobic bacilli by conventional bacteriological tests. J. med. Microbiol., 13, 231.

Duerden, B. I., HolbrooK, W. P., Collee, J. G. AND WATt, B. 1976. The characterization of clinically important gram-negative anaerobic bacilli by conventional bacteriological tests. J. appl. Bact., 40, 163.

Ellis-Pegler, R. B., Crabtree, C. and Lambert, H. P. 1975. The faecal flora of children in the United Kingdom. J. Hyg., Camb., 75, 135.

Fairchild, J. P., Graber, C. D., Vogel, E. H. JR. AND Ingersoll, R. L. 1958. Flora of the umbilical stump. J. Pediat., 53, 538.

GILliEs, R. R. AND DodDs, T. C. 1976. Bacteriology illustrated, Churchill Livingstone, Edinburgh.

GylleNBERG, H. AND RoINE, P. 1957. The value of colony counts in evaluating the abundance of "Lactobacillus" bifidus in infant faeces. Acta path. Microbiol. scand., 41, 144.

HAFIZ, S. AND OAKLEY, C. L. 1976. Clostridium difficile: isolation and characteristics. J. med. Microbiol., 9, 129.

HARDIE, J. M. AND Bowden, G. H. 1974. The normal microbial flora of the mouth. In: The normal microbial flora of man, edited by F. A. Skinner and J. G. Carr, Society for Applied Bacteriology, symposium series no. 3, Academic Press, London.

HaRGiss, C. AND LaRSON, E. 1978. Epidemiology of Staphylococcus aureus in a newborn nursery from 1970 through 1976. Pediatrics, Springfield, 61, 348.

HARVEY, D. 1979. Staphylococcal infections. J. antimicrob. Chemother., 5, suppl. A, 21.

Holbrook, W. P., Ogston, S. A. AND Ross, P. W. 1978. A method for the isolation of Bacteroides melaninogenicus from the human mouth. J. med. Microbiol., 11, 203.

Holve, L. S. AND SMITH, F. M. 1955. Omphalitis and peritonitis in the neonatal period. U.S. arm. Forces med. J., 6, 491.

HURST, V. 1957. Fusiforms in the infant mouth. J. dent. Res., 36, 513.

ISBISTER, C. 1951. Clinical study of infections of the newborn occurring in maternity hospital over a six month period. Med.J. Aust., $2,386$.

JeLLARD, J. 1957. Umbilical cord as reservoir of infection in a maternity hospital. Brit.med.J., $1,925$.

Johnson, J. D., Malachowski, N. C., Vosti, K. L. And Sunshine, P. 1976. A sequential study of various modes of skin and umbilical care and the incidence of staphylococcal colonization and infection in the neonate. Pediatrics, Springfield, 58, 354.

LAY, K. M. AND RUSSELL, C. 1972. Longitudinal study of the prevalence of Candida species in the mouths of infants. J. dent. Res., 51, 1237.

LoNG, S. S. AND Swenson, R. M. 1977. Development of anaerobic faecal flora in healthy newborn infants. J. Pediat., 91, 298.

McCarthy, C., SNyder, M. L. AND Parker, R. B. 1965. The indigenous oral flora of man I. The newborn to the one year old infant. Archs oral Biol., 10,61.

MCGEACHIE, J. AND KenNEDY, A. C. 1963. Simplified quantitative methods for bacteriuria and pyuria. J. clin. Path., 16, 32.

Mata, L. J., Mejicanos, M. L. AND Jimenez, F. 1972. Studies on the indigenous gastro-intestinal flora of Guatemalan children. Amer. J. clin. Nutr., 25, 1380.

MatA, L. J. AND URRUTIA, J. J. 1971. Intestinal colonization of breast-fed children in a rural area of low socio-economic level. Ann. N.Y. Acad. Sci.., 176, 93.

Mortimer, E. A., JR., Wolinsky, E., GonZaGa, A. J. AND RammelKamp, C. H., JR. 1966. Role of airborne transmission in staphylococcal infections. Brit. med. J., 1, 319.

Nolte, W. A. 1977. Oral Microbiology, 3rd ed., C.V. Mosby Co., St Louis. 
Payne, M. C., Wood, H. F., Karakawa, W. and Gluck, L. 1965. A prospective study of staphylococcal colonization and infections in newborns and their families. Am.J. Epidem., 82, 305.

ROTIMI, V. O., FAULKNER, J. AND DUERDEN, B. I. 1980. Rapid methods for the identification of clinical isolates of gram-negative anaerobic bacilli. Med. lab. Sci., 37, 331.

Shinebaum, R., COOKE, E. M. AND Brayson, J. C. 1979. Acquisition of Klebsiella aerogenes by neonates. J. med. Microbiol., 12, 201.

Smith, M. F., Borriello, S. P., Clayden, G. S. and Casewell, M. W. 1980. Clinical and bacteriological findings in necrotising enterocolitis: a controlled study. J. inf., 2, 23.

SocransKy, S. S. 1970. Relationship of bacteria to the etiology of periodontal diseases. $J$. dent. Res., 49, 203.

Socransky, S. S. AND Manganiello, S. D. 1971. The oral microbiota of man from birth to senility. J. Periodont., 42, 485.

Williams, C. P. S. AND Oliver, T. K., JR. 1969. Nursery routines and staphylococcal colonization of the newborn. Pediatrics, Springfield, 44, 640.

Willis, A. T. 1977. Anaerobic bacteriology, 3rd ed., Butterworth, London, p. 111.

Willis, A. T., Bullen, C. L., Williams, K., FAGg, C. G., Bourne, A. AND Vignon, M. 1973. Breast milk substitute: a bacteriological study. Brit. med. J., 4, 67.

WiLson, G. S. AND Miles, A. A. 1975. Topley and Wilson's principles of bacteriology, virology and immunity, 6th edition, vol. II, Edward Arnold, London, p. 2249.

ZINNER, D. D. AND JABLON, J. M. 1969. Cariogenic streptococci in infants. Archs oral. Biol., $14,1429$. 